\title{
The Relationship Between Teeth Brushing Behaviour With Dental Plaque Maturity Level in Primary School
}

\author{
Mutiara Rina Rahmawati Ruslan ${ }^{1}$ and Putri Arika Jayanti ${ }^{2}$ \\ \{mutiara.ruslan@dsn.moestopo.ac.id ${ }^{1}$, arikaptr12@gmail.com² \}
}

${ }^{1}$ Dental Public Health Department, Universitas Prof. Dr. Moestopo Jakarta, Indonesia

${ }^{2}$ Clinical Programme, Faculty Of Dentistry, University of Prof. Dr. Moestopo, Indonesia

\begin{abstract}
Brushing teeth is a means of maintaining dental and oral hygiene which aims to prevent dental caries. Primary school age is the appropriate time to train and to lay on correct habit and behaviour in brushing teeth. The behaviour and habit of brushing teeth will affect the occurrence of dental plaque accumulation. The accumulation of plaque that attach to the teeth for a long period of time, and is not immediately cleaned, will increase the maturity level of dental plaque, and may potentially grow into dental caries. This study aims to identify the relationship between the behaviour of brushing teeth with the level of dental plaque maturity.An analytical study with cross-sectional design, with the number of samples as many as 83 children and is determined by purposive sampling. Completion of questionnaires to assess knowledge, attitude, action, and habit of teeth brushing and using the Tri Plaque ID Gel to measure the maturity level of dental plaque. Using the Spearmen test acquired $p=0,000(p<0,005)$ and $r=0,632$. It shows that there is a relationship between good behaviour in brushing teeth and the decrease on the level of maturity of dental plaque. There is a relationship between the behaviour and habit of brushing teeth with the maturity level of dental plaque. The better the behaviour is and the habit in brushing teeth, the lower level of dental plaque maturity.
\end{abstract}

Keywords : Knowledge, Attitude, Action, and Habit

\section{Introduction}

Based on Basic Health Research Data (RISKESDAS) 2013, the national prevalance for dental and oral health issue is $25,9 \%$. Dental caries is the most common dental and oral disease in Indonesia.(1) Approximately, 70\% of dental caries found are early caries.(2) Dental caries mostly occurs among children and adoslescents. If left untreated, dental caries will affect the quality of life, both general health as well as dental and oral health(3). The precipitating factor for dental caries is an acid produced from glucose fermentation in carbohydrates and bacteria in dental plaque.(4)

Plaque is a thin, colorless layer, containing a collection of bacteria, always formed in the mouth, attached to the surface of the tooth, and when mixed with sugar in the food will produce acid.(5) Dental plaque that attached to the surface of the teeth and left for a long period of time without the necessary plaque control both mechanically (brushing teeth) and chemically, will increase the plaque maturity. As a result, it will increase the risk of dental caries. One simple method to identify the maturity level of dental plaque is by using Tri 
Plaque ID Gel (TPID). TPID is used to evaluate the maturity level of dental plaque and to assess the risk of dental caries by showing the three colours an indicator of dental plaque maturity.(6) The Tri Plaque ID Gel will turn to light blue when the sucrose in Tri Plaque ID Gel is metabolised by acidogenic bacteria in plaque ( $\mathrm{pH}$ is less than five which is the risk of dental caries). The purple or blue colour are plaques which were formed at least in 48 hours. The pink or red colour shows a newly formed plaque. $(7,8)$

Behaviour is one of the indirect factors or external factors that has an impact on dental caries.(9) Behaviour is the most dominant factor affecting dental and oral health status.(10) It is a result of all kinds of human interaction and experiences with the environment in the form of knowledge, attitude, and action.(11)

Hence, based on the description above, a study of relationship between tooth brushing behaviour with dental plaque maturity level among primary school students at Grogol Selatan 13 Public Primary School was conducted. This particular school is part of School Dental Health Program (UKGS), Faculty of Dentistry, University of Prof. Dr. Moestopo (Religious). It is crucial to teach as to foster good habit of brushing teeth for children of primary school age which aims to prevent early dental caries.

\section{Method}

This research is an analytical research with cross-sectional design. The research was carried out at Grogol Selatan 13 Public Primary School in Jakarta for year 4-6 students. Sampling taken was using purposive sampling method from 83 respondents who satisfied the inclusion criteria. Univariate analysis was carried out to determine the fequency of sample distribution. Bivariate analysis was carried out to ascertain the relationship between tooth brushing behaviour with the maturity level of dental plaque. Validity and relativity test for questionnaire were used. The analysis test was using Spearman correlation test.

Tools and materials used were questionnaire forms, Tri Plaque ID Gel, cotton bud/microbrush, mouth mirror, toothbrush, and rinse cup. The reseach subject were year 4-6 students. Students were required to fill out the questionnaire form in order to assess their behaviours which include knowledge, attitude, action and habit of brushing teeth. Furthermore, the maturity level of dental plaque was determined based on Tri Plaque ID Gel discoloration on the tooth surface sample by using toothbrush, cottonbud/microbrush. The light blue colour indicates a matured plaque that produces acid and has a risk of causing dental caries, was given score 3 . The purple or dark blue colour indicates a matured plaque but has not yet producing acid, was given score 2 . Pink or red colour indicates a newly formed plaque right after brushing teeth, was given score $1.7,8$

\section{Result and Discussion}

The research shows that there were more female than male school children participating in the study: 48 female students $(57,83 \%)$ and 35 male students $(42,17 \%)$. The largest age group were students of 11 years old $(39,76 \%)$ or 33 students, 26 students of 10 years old $(31,32 \%), 15$ students of 12 years old $(18,07 \%), 5$ students of 9 years old $(6,02 \%)$, and 4 students of 13 years old $(4,81 \%)$ the lowest number of participants in the study (see table 2 ). 
Table 1. Subjects' Characteristic Based on Sex

\begin{tabular}{lll}
\hline Subject Sex & Total & Percentage (\%) \\
\hline Male & 35 & 42,17 \\
Female & 48 & 57,83 \\
Total & 83 & 100 \\
\hline
\end{tabular}

Table 2. Subjects' Characteristic Based on Age

\begin{tabular}{lcc}
\hline Subject Age & Total & Percentage $(\%)$ \\
\hline 9 years old & 5 & 6,02 \\
10 years old & 26 & 31,32 \\
11 years old & 33 & 39,76 \\
12 years old & 15 & 18,07 \\
13 years old & 4 & 4,81 \\
\hline Total & 83 & 100 \\
\hline
\end{tabular}

Result of data analysis as follows:

Table 3. Subjects' Knowledge and Habit of Brushing Teeth

\begin{tabular}{lcc}
\hline Category & Total & Percentage (\%) \\
\hline Good & 65 & 78,31 \\
Bad/Lower & 18 & 21,69 \\
\hline Total & 83 & 100
\end{tabular}

Table 3 indicates that there were 65 students $(78,31 \%)$ with good level of knowledge and 18 students $(21,69 \%)$ with lower level of knowledge of brushing teeth among year 4-6 students at Grogol Selatan 13 Public Primary School.

Table 4. Subjects' Attitude and Habit of Brushing Teeth

\begin{tabular}{lcc}
\hline Category & Total & Percentage(\%) \\
& & \\
\hline Good & 81 & 97,59 \\
Bad/Lower & 2 & 2,41 \\
\hline Total & 83 & 100 \\
\hline
\end{tabular}

Table 4 shows that there were 81 students $(97,59 \%)$ with good attitude and good habit of brushing teeth and 2 students $(2,41 \%)$ only with bad/lower attitude and habit of brushing teeth.

Table 5. Subjects' Action regarding Method of and Brushing Teeth Habit

\begin{tabular}{lcc}
\hline Category & Total & Precentage (\%) \\
& & 89,16 \\
Good & 74 & 10,84 \\
Bad/Lower & 9 & 100 \\
\hline Total & 83 & \\
\hline
\end{tabular}


The assessment of action in this study was divided into 4 criterias namely the value of 0 is for a complete absence of action (no action), value 1 is for rarely acted upon (rare action), value 2 is for frequent action, and value 3 is for constant or routine action. Table 5.5 shows a total number of students in year 4-6 at Grogol Selatan 13 Public Primary School who have taken good action were 74 students $(89,16 \%)$, and 9 students $(10,84 \%)$ with bad/lower rate of action.

Tabel 6. Dental Plaque Maturity Level

\begin{tabular}{lcc}
\hline Plaque Maturity Level & Total & Percentage (\%) \\
\hline High & 7 & 8,43 \\
Moderate & 68 & 81,93 \\
Low & 8 & 9,64 \\
& & 100 \\
\hline Total & 83 & \\
\hline
\end{tabular}

The maturity level of dental plaque was assessed based on color changes seen on the surface of the subject's teeth after Tri Plaque ID Gel was applied. Score 3 was given to Tri Plaque ID Gel that turned into light blue. A purple or dark blue was given a score of 2. A pink or red color was given a score of 1 .

Based on table 6 , there were 7 students $(8,43 \%)$ with high level of dental plaque maturity, 68 students $(81,93 \%)$ with moderate level of dental plaque that has not yet produced acid, and 8 students $(9,64 \%)$ with low level of dental plaque which is a newly formed of plaque.

Table 7. Frequency Distribution of Knowledge of Ways and Tooth Brushing Habits with Dental Plaque Maturity Level

\begin{tabular}{lccccc}
\hline Category & & & & \\
& & High & Medium & Low & Total \\
\hline Good & 1 & 56 & 8 & 65 \\
Poor/Less & 6 & 12 & 0 & 18 \\
\hline Total & 7 & 68 & 8 & 83 \\
\hline
\end{tabular}

Based on table 7 there were 6 students with poor knowledge and high level of plaque maturity, 56 students have good knowledge with moderate plaque maturity, 12 students have poor/less knowledge with moderate level of plaque maturity, 8 students with high level of knowledge and low plaque maturity.

Table 8 Frequency Distribution of Tooth Brushing Attitude and Habits with Dental Plaque Maturity Level

\begin{tabular}{lccccc}
\hline Category & & & & \\
& Plaque Maturity Level & High & Medium & Low & Total \\
\hline Good & 7 & 66 & 8 & 81 \\
Bad & 0 & 2 & 0 & 2 \\
\hline Total & 7 & 68 & 8 & 83 \\
\hline
\end{tabular}

Table 8 shows that there were 7 students with good attitude and high level of plaque maturity, 66 students have good attitude with a moderate level of plaque maturity and 2 
students have bad attitude with moderate plaque maturity and 8 students have good attitude with low plaque maturity level.

Table 9 Frequency Distribution of Action and Tooth Brushing Habits with Dental Plaque Maturity Level

\begin{tabular}{lccccc}
\hline Category & & & & \\
& & High & Medium & Low & Total \\
\hline Good & 4 & 62 & 8 & 74 \\
Bad/Less & 3 & 6 & 0 & 9 \\
\hline Total & 7 & 68 & 8 & 83 \\
\hline
\end{tabular}

Table 9 shows that there were 4 students who acted upon well with high level of plaque maturity, 3 students with unsatisfactory action and high level of plaque maturity, 61 students who acted upon well with moderate level of plaque maturity, 6 students with unsatisfactory action and moderate level of plaque maturity, 8 students who acted upon well with low level of plaque maturity.

Table 10. Relationship of the Behaviour and Tooth Brushing Habits with Dental Plaque

\begin{tabular}{llcccc}
\multicolumn{5}{c}{ Maturity Level } \\
\hline & & Knowledge & Attitude & Action & $\begin{array}{c}\text { Plaque } \\
\text { Maturity Level }\end{array}$ \\
\hline Plaque & Correlation & -.421 & -.550 & -.358 & 1.000 \\
Maturity Level & Coefficient & & & & \\
& Sig. & .000 & .000 & .001 & \\
& $\mathrm{~N}$ & 83 & 83 & 83 & 83 \\
\hline
\end{tabular}

* Spearman Test, CI 90\%, p < 0,005

Based on the results of statistical calculations, the result of Spearman correlation test for knowledge table indicates the value of $p=0,000(p<0,05)$ and $r=-0,421$. This particular result shows that there is a relationship between knowledge of ways and habits of brushing teeth with the subject's dental plaque maturity level. The better the behaviour and habits of brushing teeth, the lower level of plaque maturity. Further, for the attitude indicates the value of $p=0,000(<0,05)$ and $r=-0,550$ shows that there is a relationship between the attitude about ways and habit of brushing teeth with the level of dental plaque maturity. The better of the attitude about ways and habits of brushing teeth, the lower level of dental plaque maturity. Finally, for action, indicates the value of $p=0.000(\mathrm{p}<0,05)$ means that there is a significant correlation between variables that are connected, and in this study shows the correlation coefficient value of $r=-0,632$ means that when the level of action of ways and habit of brushing teeth is increasing, then the level of dental plaque maturity will decrease and the hypothesis proposed by the researcher is accepted.

The research had been conducted at Grogol Selatan 13 Public Primary School for year 46 students. There were 83 students participated on the research, comprised of 48 female students and 35 male students. The result shows that there were 65 students with good knowledge and 18 students with poor knowledge. The relationship between knowledge about the way/method of and habit of brushing teeth with the level of dental plaque maturity through Spearman correlation test shows the value of $p=0,000(p<0,05)$ and $r=-0,421$. This particular test shows that there is correlation between the subject's knowledge of the way and the habit of brushing teeth with the level of dental plaque maturity. The better the behaviour of 
ways and habits of brushing teeth of the subject's, the lower level of dental plaque maturity of the subject's. This is in line with research conducted by Irmanita W. et al at the Primary School in Gajahmungkur sub-district Semarang City (2013). This particular research showed that students' knowledge of tooth brushing will have good and bad impact on their dental and oral hygiene, and consequently will affect the score or accumulation of dental plaque. However, it is not sufficient neither a guarantee that the accumulation of dental plaque can be lowered down for someone who has an excellent knowledge but not applying the knowledge into daily action or on the person's daily behaviour. This theory is also aligned with Lawrence Green's theory, stated that health behaviour is shaped by several factors, one of which is people's knowledge toward health.(32). It is not enough for students who have already knew about the daily required on the frequency of brushing teeth and understand it, but not applying them into action. According to the research conducted by Gopdianto et al at Malalayang Public Primary School (2015), students who already knew about the frequency of brushing teeth may be due to their existing knowledge of the right frequency of brushing teeth due to parental guidance and health information (18). Having a good knowledge about the ways and habits of brushing teeth may be reflected upon the right attitude and actions, as knowledge is a cognitive domain which is highly significant for the formation of actions (overt behaviour).(31) Knowledge based behaviour will last longer than the alternative.

The results of the study also showed that there were 81 students in year $4-6$ at Grogol Selatan 13 Public Primary School with good attitude about the way and habits of brushing teeth, and there were 2 students with poor/lower attitude. The relationship of attitudes about the way and habits of brushing teeth with the level of dental plaque maturity, shows the results with the value of $\mathrm{p}=0,000(<0,05)$ and $\mathrm{r}=-0,550$ which indicates that there is a relationship between attitude about the way and habit of brushing teeth with the level of maturity of dental plaque and the better the attitude about the way and habit of brushing teeth are, the lower level of maturity of dental plaque.

The outcome of this study shows that most subjects of 74 students are performing well in terms of ways and habits of brushing teeth. The relationship between method of action and habits of brushing teeth with the maturity level of dental plaque, obtained a result with the value of $\mathrm{p}=0,001(<0,05)$ and $\mathrm{r}=-0,358$ indicates that there is a relationship between actions regarding the way and habits of brushing teeth with the maturity level of dental plaque and the better the action regarding ways and habits of brushing teeth, the lower level of maturity of dental plaque.

In general, based on the statistical test, it was found that there was a relationship between the behaviour and habits of brushing teeth with the level of dental plaque maturity in year 4-6 at Grogol Selatan 13 Public Primary School, showing that the knowledge, attitude, and action obtained the value of $p<0,05$ which means that there is a significant relationship between the variables that are connected known as behaviour (knowledge, attitude, and action) ways and habits of brushing teeth with the level of maturity of plaque. Consequently, the hypothesis proposed by the researcher is accepted.(16)

The maintenance effort for dental and oral health should be done from an early age. Primary school age is an ideal time to train a child's motor skills, including brushing teeth. Behaviour could not be learned overnight, but gradually over the years as the child develops. Children at school age are very active in learning what is in their environment, therefore, the urge to explore and to act upon towards their environment are tremendous. Consequently, children are easy to be guided, to be directed, and to be instilled with good habits.

Based on Piaget's theory of cognitive development, the intellectual ability of children aged 6-12 is sufficient to be used as the basis for dispensing various skills to foster their 
mindset or reasoning power. It is then envisaged that the knowledge will raise an awareness, which in turn will make them to behave in accordance with their knowledge.(32)

\section{Conclusion}

The research outcome gathered from Grogol Selatan 13 Public Primary School students year 4-6 indicates that the majority of students have good knowledge with moderate level of plaque maturity. The result may well be due to the fact that Grogol Selatan 13 Public Primary School is one of UKGS (School Dental Health Program) participants, initiated and guided by Dentistry Faculty University of Prof. Dr. Moestopo (Religious) that receives regular education on dental and oral health promotion. However, if the school receives a routine dental and oral health education, a low level of plaque should be expected. This situation may well be due to the fact that students were cooperating with each other when giving their answer on the questionnaires. In addition, the moderate level of plaque maturity is still existed among students with good attitude and action but with poor knowledge, yet, knowledge based behaviour will last longer compare to the opposite. Nonetheless, knowledge on its own is not sufficient to change one's behaviour if it is not being put into daily practice, and other influencing factors. It is then recommended that shared brushing teeth activities between students and teachers be conducted regularly at the school. The educations is aiming not only for students but can also be directed at teachers and students' parents which can be done continuously with better plan, and better direction through UKGS health promotion activities. Other researchers may be able to conduct further research by examining different risk factors that influence the maturity level of dental plaque, using other measurement tools so that early prevention of dental caries can be implemented immediately for students at Grogol Selatan 13 Public Primary School.

\section{References}

[1]. Fatimatuzzahro N, Prasetya RC, dan Amilia W. Overview of Primary School Dental Behaviour in Bangsalsari Village, Jember Regency, IKESMA Journal, 2016. 12(2).

[2]. Health Research and Development Agency. Basic Health Research (RISKESDAS) 2013. National Report. 2013. 110-119.

[3]. Reddy K, Reddy S, Ravindhar P, Balaji K, Reddy H, and Reddy A. Prevalence of Dental Caries among 6-12 Years School Children of Mahbubnagar District, Telangana State, India: A Cross-sectional Study. Indian Journal of Dental Sciences. 2017; 1-4 https://doi.org/10.4103/0976-4003.201641.

[4]. Angela A. Primary Prevention for Children with High Risk of Caries, Dentistry Magazine. (Dent. J.). 2005; 38(3): 130-134.

[5]. Anitasari S, Rahayu NE. The Relationship Between the Frequency of Brushing Teeth with Public School Students' Level of Dental and Oral Hygiene at Palaran District, Samarinda Council, East Kalimantan Province. Dental Journal. 2005. 38(2): 88-90.

[6]. Jayanthi M, Shilpapriya M, and Vijayakumar P. Efficacy of Three-Tone Disclosing Agent as an Adjunct in Caries Risk Assessment. Contemporary Clinical Dentistry. 2015. 6(3): 358-363.

[7]. Tugeman H, Rahman NA, Yusoff A, and Daud MK. Oral Health Knowledge, Practice, and Dental Plaque Maturity Status of Hearing-Impaired Children. Sains Malaysiana. 2016. 761-768. 
[8]. Laurence J. Walsh. GC Tri Plaque ID Gel. 2011. Downloaded from http://www.gcamerica.com/products/preventive/gc tri_plaque id/gc triplaque id gel sellsheet.pdf dated 24 Agustus 2018.

[9]. Miftakhun NF, Sunarjo L, Mardiati E. External Factors that Cause Dental Caries in Pre School Children at PAUD Strowberry RW 03 Bangetayu Wetan Sub-dictrict, Semarang City year 2016. Dental Health Journal. 2016. 3(2): 27-34.

[10]. Pay MN, Widiati S, Sriyono NW. Factors Identificaton Affecting Children's Behaviour in Dental and Oral Hygiene Maitenance: Study at Agape Child Development Centre Sikumana, Kupang City, Nusa Tenggara Timur, Indonesia. Indonesian Dentistry Magazine. 2016. 2(1): 27 - 34.

[11]. Budiharto. Introduction to Health Behavioural Sciences and Dental Health Education. Jakarta: EGC; 2015: 1-3.

[12]. Hestieyonini H. Maintaining Behaviour of Dental and Oral Health for Students at AlAzhar Islamic Boarding School Jember. Dentistry Journal Unej. 2013. 10: 17-20.

[13]. Ahameed S et al. Evaluation of the Oral Health Knowledge, Attitude and Behaviour of the Preclinical and Clinical Dental Students. Journal of International Oral Health. 2015. 7(6): 65-70.

[14]. Newman M, Takei H, Klokkevold P, and Carranza F. Carranza's Clinical Periodontology, $11^{\text {st }}$ ed. Elsevier; 2012: 455 - 456.

[15]. Eley BM, Soory M, Manson JD. Periodontics, $6^{\text {th }}$ ed. New York: Elsevier; 2010: 153.

[16]. McRae Dental Associates. How to Brush Your Teeth. 2018. Downloaded from: http://www.mcraedentalassociates.com/patient-education/brush-teeth/ dated 14 Maret 2018.

[17]. Budisuari MA, Oktarina O, dan Mikrajab MA. Relationship between Diet and Tooth Brushing Habits with Dental and Oral Health (Caries) in Indonesia. Health Research Bulletin. 2010. 13(1): 130-138.

[18]. Gopdianto R, Rattu AJM, dan Mariati NW. Oral Hygiene Status and Children's Behaviour of Brushing Teeth at Malalayang 1 Public Primary School. e-Dental Journal (eG). 2015. 3(1): $624-632$.

[19]. Hastuti S, Andriyani A. The Distinction of the Influence of Dental Health Education in Increasing Children's knowledge of Dental Health at Public Primary School 2 Sambi, District Samba Boyolali Regency. GASTER. 2010. 7(2): 625.

[20]. Murray JJ, Nunn JH, and Steele JG. The Prevention of Oral Disease, $4^{\text {th }}$ ed. United States: Oxford University Press; 2003: 153.

[21]. Onisei D, Onisei D, Feier I, Rusu D, and Stratul S. The Biofilm: Formation and Removal. TMJ; 2008: 111 - 117.

[22]. Manson JD, Eley BM. Periodontology Textbook. In: Anastasya (Translator). Jakarta: Hipokrates; 1993: 23-25.

[23]. Chetrus V, Ion IR. Dental Plaque - Classification, Formation, and Identification. International Journal of Medical Dentistry. 2013; 3: 139 - 143.

[24]. Mount J, Hume R. W. Preservation and Restoration of Tooth Structure, $2^{\text {nd }}$ ed. Queensland: Knowledge Books and Software; 2005. 22-25.

[25]. Sirat N. M. Soft Food Risk Dental Health. Dental Health Journal. 2013. 1(2): 132 137.

[26]. Penda PAC, Kaligis SHM, dan Juliatri. The Distinction in Plaque Index Before and After Chewing Apple. e-GIGI Journal (eG). 2015. 3: 381.

[27]. Marya CM. A Textbook of Public Health Dentistry. New Delhi: Jaypee Brothers Medical Publishers (P) LTD; 2011: 190-191. 
[28]. Novita CF, Andriany P, dan Helmi RD. Overview of Clinical Students' Compliance Faculty of Dentistry Syiah Kuala University Regarding Separation of Medical and Non Medical Waste. Journal of Syiah Kuala Dentistry Society. 2017. 2(1): 26-32.

[29]. Vaus D.A. Survey in Social Research, ${ }^{\text {th }}$ ed. New South Wales: Allen and Unwin; 2002: 259 .

[30]. Nasrullah M, Suwandi T. Relationship Between Workers' Knowledge, Attitude, Safe Practice Behaviour in an Attempt to Uphold Occupational Safety and Health. Airlangga University Journal. 2014. 2(1): 83.

[31]. Harahap RA. Effect of Predisposing, Enabling, and Reinforcing Factors on Giving Hepatitis B Immunisation to Infants at Bagan Batu Community Health Centre (Puskesmas) Bagan Sinembah District Rokan Hilir Regency. Jumantik Journal. 2016. 1 (1): 89 .

[32]. Sari EK, Ulfiana E, Dian P. The Effect of Tooth Brushing Health Education with Snakes and Ladder Simulation Game Methods to Change Knowledge, Attitude, and Application of School-Age Children Tooth Brushing Action at Primary School Paron Ngawi Area. Airlangga University Journal. 2012. 2. 